\title{
PRÁCE ŠKOLNÍHO PSYCHOLOGA SE TŘÍDOU NA ZÁKLADNÍCH ŠKOLÁCH
}

\author{
Kateřina Palová, Jan Šmahaj
}

\section{Abstrakt}

Práce se třídami představuje v rámci náplně práce školního psychologa značný podíl. O tom, jak často a jakou formou školní psychologové na základních školách se třídami pracují, víme opravdu málo. Cílem našeho výzkumu bylo zjistit zastoupení práce se třídou v činnosti školního psychologa, popsat, jakým způsobem školní psychologové se trrídami nejčastěji pracují, a prozkoumat subjektivní hodnocení vlastní kompetence školních psychologů při práci se třídou. Soubor respondentů tvořilo 73 školních psychologů základních škol. Data byla sbírána prostřednictvím on-line dotazníku vlastní konstrukce. Výsledky poukazují, že práce se třídou je třetí nejčastěji uváděnou činností pracovní náplně školního psychologa. Školní psycholog vstupuje do tříd nejčastěji na žádost třídní učitelky $(38,26 \%)$, pravidelně na základě vlastní iniciativy $(31,51 \%)$ nebo když má dojem, že by to dané tř́́dě mohlo pomoci $(20,55 \%)$. Subjektivní hodnocení kompetence školních psychologů v práci s třídními kolektivy mimo jiné ovlivňují výše úvazku, délka praxe a další vzdělávání zaměřené na práci se třídou. Signifikantní rozdíly ve stanovených kritériích však nebyly potvrzeny.

Klíčová slova: školní psycholog, školní psychologie, základní škola, třídní klima, prevence

\section{SCHOOL PSYCHOLOGISTS AND CLASSWORK IN THE PRIMARY SCHOOLS}

\begin{abstract}
Classwork takes a considerable amount of school psychologists' work. However, we know little about the frequency and form of their work with the class. We have defined three main goals of our research. First, to set the proportion of time school psychologists to work with the class. Second, to describe the form of their work with the class. And third, to evaluate their subjective competencies for work with the class. The sample consisted of 73 school psychologists working in primary schools. The data were collected using an online self-made questionnaire. The results show that classwork is the third most common activity of school psychologists. School psychologists most often start their classwork upon request from a teacher (38,26\%), regularly as their initiative $(31,51 \%)$ or if they find out that a class needs extra support $(20,55 \%)$. Subjective level of competence to classwork is influenced especially by the level of workload, length of experience in the field and specialised training in work with groups. However, the difference between the criteria was not significant.
\end{abstract}

Keywords: school psychologist, school psychology, primary school, school climate, prevention

Došlo: 25. 1. 2019

Schváleno: 11. 12. 2019 


\section{Úvod}

Školní psychologie jako obor se v posledních letech čím dál více dostává do povědomí laické veřejnosti. Co je důležitější, také ředitelé škol si začínají uvědomovat, že služby odborníka mohou být pro jejich školu užitečné. Často tak využívají nových možností, jak pozici školního psychologa v dané škole zavést. Školním psychologem se v posledních letech často stávají čerství absolventi, kteří to považují za dobrou př́ležitost získat hned po škole práci. Ač mnohdy s velkým pracovním nasazením, ale dost často s žádnou nebo minimální zkušeností z oboru, se vrhají do práce, která je svou rozmanitostí velmi náročná.

V rámci náplně práce školního psychologa představuje práce se tř́dami značný podíl. Jedná se o téma aktuální a zároveň s nedostatečnou oporou v odborné literatuře. $\mathrm{O}$ tom, jak často a jakou formou školní psychologové ve školách se třídami pracují, víme opravdu málo.

\section{Vymezení školní psychologie a náplň práce školního psychologa}

Vymezení pojmu školní psychologie, respektive školní psycholog, se v minulosti věnovalo již mnoho odborníků (např. Hvozdík, 1986; Lazarová, 2008; Gajdošová, Herényiová, \& Valihorová, 2010). Pro účely tohoto textu se opíráme o definici Kavenské, Smékalové a Šmahaje (2011, 59), kteří školní psychologii popisují jako „mladou, perspektivní, specializovanou psychologickou vědu, jejiž zaměření vychází ze spojení pojmů psychologie a škola. Zaměřuje se na psychologické aspekty procesů a jevů, které se ve škole vyskytují, a subjektů, které se na fungování školy podileji. “. Přestože lze počátky školní psychologie nalézat již na přelomu 19. a 20. století (Štech \& Zapletalová, 2013), k jejímu většímu rozvoji dochází teprve po roce 1989 (Lazarová, 2008).

Na konci 90. let, což považujeme za pomyslný počátek ustanovování školní psychologie jako svébytné vědy, se postupně začaly objevovat práce mapující činnosti školních psychologů, které výrazně napomohly ukotvení této profese v zákoně o pedagogických pracovnících. Tyto výzkumy obvykle srovnávají očekávání učitelů či ředitelů s činnostmi, které školní psycholog skutečně realizuje. Konstatujeme, že v obou těchto kategoriích se práce se tř́́dou či se skupinou objevuje (viz Lazarová \& Ondruš, 2000; Štech, 2001; Štech \& Zapletalová, 2001).

Výzkum v oblasti školní psychologie se pozvolna přesouvá z bazálních témat ke konkrétním oblastem práce školního psychologa, jako je např́klad diagnostika klimatu školy (Ježek, 2006), výzkumná činnost (Mareš, 2016) či podpora duševního zdraví žáků (Pilková, 2017). $\mathrm{Z}$ obecnějších témat to pak jsou třeba kritická místa profese (Keřt, 2014) nebo morální distres (Mareš, 2017).

V zahraniční literatuře často nacházíme zmínky o nutnosti pozitivního rozvoje dětí ve školách, aplikaci poznatků z oblasti pozitivní psychologie a podpoře duševního zdraví žáků (např. Seligman, Ernst, Gillham, Reivich, \& Linkins, 2009; Waters, 2011), což se s profesí školního psychologa významně pojí. Např́klad Gajdošová (2017) v návaznosti na evropskou zdravotní politiku tvrdí, že jednou z hlavních úloh školního psychologa by měla být podpora duševního zdraví všech osob zapojených do vzdělávacího procesu, tj. žáků, učitelů i dalších pracovníků, 
a realizace s tím souvisejících preventivních programů, nejlépe střednědobých a dlouhodobých. Tyto programy by měly být zaměřeny na témata jako řešení konfliktů nebo rozvíjení empatie. Školní psycholog by měl duševní zdraví řešit v rovině individuální, školní, rodinné i společenské. Nedílnou součástí jeho práce by měla být také identifikace pozitivních stránek jednotlivých subjektů a řešení patologických jevů za využití pozitivní psychologie (Gajdošová, 2017). Odborníci zdůrazňují staronovou roli školního psychologa jako někoho, kdo bude podporovat pozitivní sociální klima školy i jednotlivých tříd (Gajdošová, 2017; Lazarová, Hloušková, Pol, \& Trnková, 2017), spoluvytvářet pozitivní vztahy mezi všemi účastníky vzdělávacího procesu včetně zaměření na vztahy v rámci pedagogického sboru, metodicky zaštit'ovat rozvoj sociálně-emocionálních kompetencí (Gajdošová, 2017) a pracovat na postupném odstraňování stigmat ze systému školy (Lazarová et al., 2017).

Někteří autoři předpokládají, že se školní psycholog také aktivně podílí na výzkumu v této oblasti. Kromě všeobecného výzkumu se školní psycholog zaměřuje i na situaci vlastní školy, především ve smyslu ověřování efektivity preventivních a intervenčních programů (Merrell, Ervin, \& Peacocck, 2011).

Přestože prací zaměřených přímo na práci školního psychologa s třídním kolektivem není mnoho, lze najít poměrně široké spektrum studií, ze kterých je možné v tomto tématu čerpat. Některé z inspirativních prací jsme se pokusili shrnout $\mathrm{v}$ níže uvedené tabulce, ovšem bez ambice na vytvoření vyčerpávajícího přehledu. Pro lepší orientaci v tabulce rozlišujeme studentské práce (označené hvězdičkou) a práce zaměřené přímo na školní psychology (tučné). Jednotlivé studie také rozdělujeme do tematických kategorií, nicméně toto zařazení lze chápat jako zavádějící, nebot' se kategorie obsahově prolínají.

Tab. 1: Výběr prací zaměřených na práci školního psychologa s třídním kolektivem

\begin{tabular}{|c|c|c|}
\hline & ČR & Zahraničí \\
\hline Psychosociální klima & $\begin{array}{l}\text { Ježek }(2006)^{*} \\
\text { Melovská (2009)* } \\
\text { Čapek }(2010) \\
\text { Kozel }(2010)^{*} \\
\text { Mareš a Ježek (2012) }\end{array}$ & Hertz-Lazarowitz a Od-Cohen (1992) \\
\hline Prevence & Palová a Smékalová (2019) & $\begin{array}{l}\text { Branden-Muller a Elias (1991) } \\
\text { Artamonova, Efimova a Khydyova } \\
(\mathbf{2 0 1 6 )}\end{array}$ \\
\hline Intervence & $\begin{array}{l}\text { Váchová }(2016)^{*} \\
\text { Paulová }(2017)^{*} \\
\text { Titmanová (2019) }\end{array}$ & Sherer a Nickerson (2010) \\
\hline Krizová intervence & $\begin{array}{l}\text { Matasová (2012)* } \\
\text { Plachá (2017) }\end{array}$ & $\begin{array}{l}\text { Allen, Jerome, White et al. (2002) } \\
\text { Nickerson a Zhe (2004) }\end{array}$ \\
\hline $\mathrm{ŠS}_{\text {obecně }}^{1}$ & $\begin{array}{l}\text { Kavenská, Smékalová a Šmahaj (2011) } \\
\text { Lazarová, Hloušková, Pol a Trnková (2017) } \\
\text { Bartoňová, Pipeková, Viktorin a Vítková } \\
\text { (2019) }\end{array}$ & Fenning et al. (2012) \\
\hline
\end{tabular}

\footnotetext{
${ }^{1}$ Zdroje, v nichž se mluví o práci školního psychologa se třídou, ale není to hlavní téma práce.
} 
Výše uvedená tabulka prezentuje pouze některé z relevantních výzkumných prací. Je patrné, že v zahraniční odborné literatuře je zdrojů zaměřených na školní psychology výrazně více než v literatuře české, nicméně jejich aktuálnost je diskutabilní. Troufneme si konstatovat, že odborná veřejnost aktuálně směřuje trochu jiným směrem, než je práce školního psychologa se školním kolektivem.

Pro úplnost si dovolíme zmínit také některé zásadní české monografie v tématu práce se třídním kolektivem, ze kterých lze pro praxi i pro výzkum dále čerpat (seřazeno dle data vydání):

Skupinová dynamika ve školní třídě (Hermochová, 2005)

Sociálně psychologické klima školnich tříd a školy (Lašek, 2007)

Sociální dovednosti ve škole (Gillernová, Krejčová et al., 2012)

Didaktika osobnostní a sociální výchovy (Valenta, 2013)

Praktikum školní psychologie (Braun, Marková, \& Nováčková, 2014)

Psychologie školní šikany (Janošová, Kollerová, Zábrodská, Kressa, \& Dědová, 2016)

\section{Metodická podpora školních psychologů při práci se třídou}

Přestože z výše uvedených studií je patrné, že práce se třídou je něco, co školní psycholog obvykle dělá a co se od něj očekává, metodická podpora pro tuto činnost je velmi omezená. Tématu se částečně věnují Braun, Marková a Nováčková (2014) ve své knize Praktikum školní psychologie, kterou školní psychologové obvykle využívají jako základní zdroj inspirace. Podle nich se dá předpokládat, že častou zakázkou školního psychologa bude podpora pozitivního tř́́dního klimatu, prevence rozvoje patologických vztahů a intervence v těch třídách, kde se nějaký vztahový problém vyskytne.

Otvírá se tak poměrně široké spektrum témat, ve kterých by se měl školní psycholog orientovat. Měl by rozumět tomu, jakými stádii tř́dy prochází (viz Braun, 2003, in Braun et al., 2014), jak se na základě společné historie dělí (viz Smékalová \& Kolařík, 2011) nebo jaké bývají ve třídě rozdělené role (Braun et al., 2014).

Jednou z hlavních forem práce školního psychologa se třídními kolektivy jsou preventivní vstupy. Braun et al. (2014) je dle náročnosti metodických postupů a př́pravy dělí do následujících úrovní:

vedení třídy;

prožitková hodina;

tematika;

nácviky;

intervence;

krizová intervence;

supervize školní třídy. 
Preventivní vstupy do tříd ovšem nejsou to jediné, kdy školní psycholog přichází do kontaktu se trrídou. Do sbírky možných úkolů školního psychologa bychom mohli zařadit např́iklad ještě diagnostiku vztahů a třídního klimatu či realizaci adaptačních a kohezivních programů (Braun et al., 2014).

Ačkoli je práce školního psychologa se tř́dou poměrně specifická, často nezbývá než hledat metodickou podporu jinde. Užitečným zdrojem informací mohou být pro školní psychology např. metodiky zážitkové pedagogiky, která se zabývá rozvojem účastníků prostřednictvím prožitku (Slejšková, 2011) a má podrobně zpracovaná témata rozvojové práce se skupinou. Dalšími možnými zdroji inspirace a metodické podpory může být např. Etická výchova, Projekt Odyssea nebo sociálně-emocionální učení.

\section{Cíl výzkumu}

V souvislosti s tvrzením, že jednou z hlavních úloh školního psychologa by měla být podpora duševního zdraví všech osob zapojených do vzdělávacího procesu (Gajdošová, 2017), a zároveň s důrazem na roli školního psychologa jako někoho, kdo bude podporovat pozitivní sociální klima školy i jednotlivých tříd (Lazarová et al., 2017), jsme se rozhodli popsat nejen to, jak školní psychologové pracují s třídními kolektivy, ale také jaké metodické podpory se jim dostává a kterou využívají.

Výzkumné cíle

1. Popsat zastoupení práce se trrídou v činnosti školního psychologa.

2. Zjistit, jakým způsobem školní psychologové se tř́dami nejčastěji pracují.

3. Zjistit subjektivní hodnocení vlastní kompetence školních psychologů při práci se skupinou.

\section{Použité metody}

Při realizaci jsme využili dotazník vlastní konstrukce, jehož distribuce probíhala online. $\mathrm{V}$ dotazníku byly použity různé typy uzavřených i otevřených otázek. S ohledem na časovou náročnost profese školního psychologa se zvolení dotazníkové formy jevilo jako nejrychlejší forma pro získání potřebného množství dat. Při tvorbě otázek jsme se drželi základních metodických textů pro práci se tř́́dami či realizaci zážitkových programů. Některé otázky také reflektovaly naši vlastní zkušenost v práci se skupinami.

\section{Struktura použitého dotazníku}

Vytvořený dotazník měl celkem 45 otázek rozdělených do šesti částí. Účast respondentů byla anonymní a dobrovolná, průměrná doba vyplnění nepřesáhla 20 minut. V úvodní části byly umístěny všechny úvodní informace a také aktivní tlačítko pro udělení souhlasu se zapojením do výzkumu, uchováním dat a k jejich statistickému zpracování. Následovaly jednotlivé části 
(A) Upřesňující informace, (B) Distribuce času, (C) Formy práce se tř́idami, (D) Kompetence, (E) Sociálně-emocionální učení ${ }^{2}$, (F) Sociodemografické údaje. V závěrečné části dotazníku byl prostor pro další komentář respondenta, poděkování za účast ve výzkumu a emailová adresa, prostřednictvím níž může respondent zpětně získat výsledky výzkumu. Této možnosti nakonec využili čtyři respondenti. Finální verze dotazníku byla pilotně ověřena. ${ }^{3}$

\section{Metody zpracování a analýzy dat}

V první fázi zpracování dat došlo $\mathrm{k}$ exportu datové matice $\mathrm{v}$ datovém formátu .xls. Ve druhé fází byla provedena formální a logická kontrola dat. Tento proces byl nastaven během předvýzkumu a umožňoval pracovat s výsledky průběžně v rámci jednotlivých etap sběru dat. Z další statistické analýzy byly vyřazeny nekompletně vyplněné dotazníky a také dotazníky, kde byl logický rozpor či chybně vyplněné pole. Zpracování dat probíhalo částečně v systému SurveyMonkey ${ }^{4}$ a částečně pomocí statistického softwaru STATISTICA - verze 13.4. Zde jsme využili postupy pro tvorbu tabulek popisné statistiky, tabulky četností, generování histogramů a korelačních matic. Při hledání statistických souvislostí bylo využito t-testu pro dva nezávislé výběry.

\section{Sběr dat}

Sběr dat probíhal od 12. února do 19. března 2018. Pro on-line dotazování byl zvolen systém SurveyMonkey, který splňuje kritéria tohoto typu šetření (vysokou míru zabezpečení, možnost archivace a kódování během přenosu dat, přístup přes vygenerované heslo apod.)

Pro sběr dat bylo využito více komunikačních kanálů a způsobů (viz tab. 2). Přestože počet školních psychologů v ČR narůstá, neexistuje aktuální statistika, která by mohla být za tímto účelem využita. Pro oslovení respondenti̊ splňující kritérium výkonu profese školního psychologa bylo využito:

Tab. 2: Přehled způsobů oslovení školních psychologů

\begin{tabular}{l|c}
\hline Způsob oslovení & Počet reakcí \\
\hline$-\quad$ vytvoření databáze kontaktů realizátorů výzkumu a jejich př́mé oslovení; & 25 \\
\hline $\begin{array}{l}\text { žádosti směrem k respondentům, kteří vyplnili dotazníkové šetření o šíření či } \\
\text { předání výzvy formou sněhové koule; }\end{array}$ & 13 \\
\hline
\end{tabular}

\footnotetext{
2 Tato část není z důvodu rozsahu součástí analýzy výsledků. Autoři předpokládají její samostatné zpracování formou budoucího článku.

${ }^{3}$ Plné znění dotazníku je na vyžádání $\mathrm{k}$ dispozici u autorů práce.

${ }^{4}$ www.surveymonkey.com
} 


\begin{tabular}{ll|c}
\hline$-\quad$ výzvy směřuící i k pregraduálním studentům předmětu školní psychologie, aby v & 6 \\
rámci svých praxí informovali př́mo školní psychology na školách o realizovaném \\
sběru dat;
\end{tabular}

Na některou z výše uvedených výzev reagovalo celkem 170 respondentů. Po logické a formální kontrole bylo získáno 88 (51,8 \%) validních dotazníků z různých typů škol. Pro další analýzu bylo postoupeno 73 dotazníků školních psychologů základních škol. Ke snížení počtu plně vyplněných dotazníku přispělo:

a) zájem o dotazníkové šetření, ale respondent nesplňoval požadovaná kritéria,

b) nekompletní vyplnění dotazníku.

Z důvodu výše uvedené kombinace komunikačních kanálů není celkový počet potenciálně oslovených respondentů zjistitelný. V tomto př́ípadě by se jednalo o pouhý odhad.

\section{Výzkumný soubor}

Výzkumný soubor (n=73) tvořili školní psychologové základních škol ve věku 24 - 71 let, kteří $\mathrm{v}$ době sběru dat byli $\mathrm{v}$ zaměstnaneckém poměru. Průměrný věk byl 34,32 let $(\mathrm{MD}=33$, $\mathrm{SD}=8,58)$ a průměrná doba zaměstnání na současné pozici byla 3 roky a 4 měsíce (minimální doba působení byla 13 měsíců a maximální doba jednoho z respondentů byla 13 let a 3 měsíce). V souboru respondentů bylo 6 (8,22 \%) mužů a 67 (91,78 \%) žen. V 24,66 \% př́padech působili dotázaní školní psychologové na dvou školách. Pouze 10,96 \% má kromě práce školního psychologa i jiný úvazek na škole. V rámci výše úvazku převažoval poloviční úvazek (20 hodin týdně) 58,9 \%, druhý nejčastěji uváděný byl úvazek plný (40 hodin týdně) 32,88 \%. V 79,45 \% prŕípadů byla zaměstnavatelem škola, ve $20 \%$ jiná instituce či projekt a v $10 \%$ prímo kraj. Nejvíce se zapojili školní psychologové z Moravskoslezského (21, 92 \%), Olomouckého (21, 92 \%) a Jihomoravského kraje (16,44 \%), zatímco Plzeňský a Karlovarský nebyl zastoupen vůbec. Za zajímavé zjištění lze považovat skutečnost, že pouze 38,36 \% školních psychologů v našem vzorku pracuje v místě bydliště. 


\section{Výsledky}

Za významnou proměnnou v rámci sebehodnocení při práci $\mathrm{s}$ tř́ídními kolektivy vnímáme, nakolik se školní psycholog cítí přijímán na škole. Pro doplnění uvádíme v tabulce 3 subjektivní hodnocení pocitu přijetí na škole dle uvedených kritérií. Zajímalo nás také, zda věk školního psychologa (do 27 let a nad 27 let) či délka působení na současném pracovišti (adaptační fáze ve formě 30 měsíců a nad 30 měsíců) hraje ve vnímaném pocitu přijetí roli. V obou uváděných prípadech nebyla nalezena statistická významnost.

Tab. 3: Ohodnot’te, jak se v současné době cítíte přijímání jako školní psycholog na škole z hlediska následujících kritérií $(\mathrm{n}=73)$.

\begin{tabular}{|c|c|c|c|c|c|c|c|c|c|c|c|}
\hline & \multicolumn{2}{|c|}{1 nejlépe } & \multicolumn{2}{|c|}{2} & \multicolumn{2}{|l|}{3} & \multicolumn{2}{|l|}{4} & \multicolumn{2}{|c|}{5 nejhůr̆e } & \multirow{2}{*}{$\begin{array}{l}\text { vážený } \\
\text { průměr } \\
1,58\end{array}$} \\
\hline Vztah s vedením školy & $61,64 \%$ & 45 & $24,66 \%$ & 18 & $8,22 \%$ & 6 & $5,48 \%$ & 4 & - & 0 & \\
\hline Vztah s pedagogy & $24,66 \%$ & 18 & $60,27 \%$ & 44 & $13,70 \%$ & 10 & $1,37 \%$ & 1 & - & 0 & 1,92 \\
\hline $\begin{array}{l}\text { Vztah s metodikem } \\
\text { prevence }\end{array}$ & $58,90 \%$ & 43 & $27,40 \%$ & 20 & $6,85 \%$ & 5 & $5,48 \%$ & 4 & $1,37 \%$ & 1 & 1,63 \\
\hline $\begin{array}{l}\text { Vztah s výchovným } \\
\text { poradcem/poradkyní }\end{array}$ & $63,01 \%$ & 46 & $24,66 \%$ & 18 & $8,22 \%$ & 6 & $4,11 \%$ & 3 & - & 0 & 1,53 \\
\hline Přijetí ze strany žáků & $50,68 \%$ & 37 & $42,47 \%$ & 31 & $6,85 \%$ & 5 & - & 0 & - & 0 & 1,56 \\
\hline Přijetí ze strany rodičů & $30,14 \%$ & 22 & $56,16 \%$ & 41 & $12,33 \%$ & 9 & $1,37 \%$ & 1 & - & 0 & 1,85 \\
\hline
\end{tabular}

\section{Výzkumný cíl 1: Popsat zastoupení práce se třídou v činnosti školního psychologa}

Respondentům byl předložen seznam třiceti činností pracovní náplně školních psychologů, kde mohli vybrat více odpovědí. Celkem 97, 26 \% školních psychologů uvedlo práci se třídou. Jednalo se o třetí nejčastěji uváděnou činnost pracovní náplně. První nejčastěji volenou činností byla individuální práce se žákem - konzultace (100\%). Druhou príičku obsadila činnost konzultace s rodiči $(98,63 \%)$. V rámci distribuce času byli školní psychologové požádáni o rozdělení času u jednotlivých činností tak, aby celkový součet činil 100 \%. 
Graf 1: Distribuce času vybraných činností

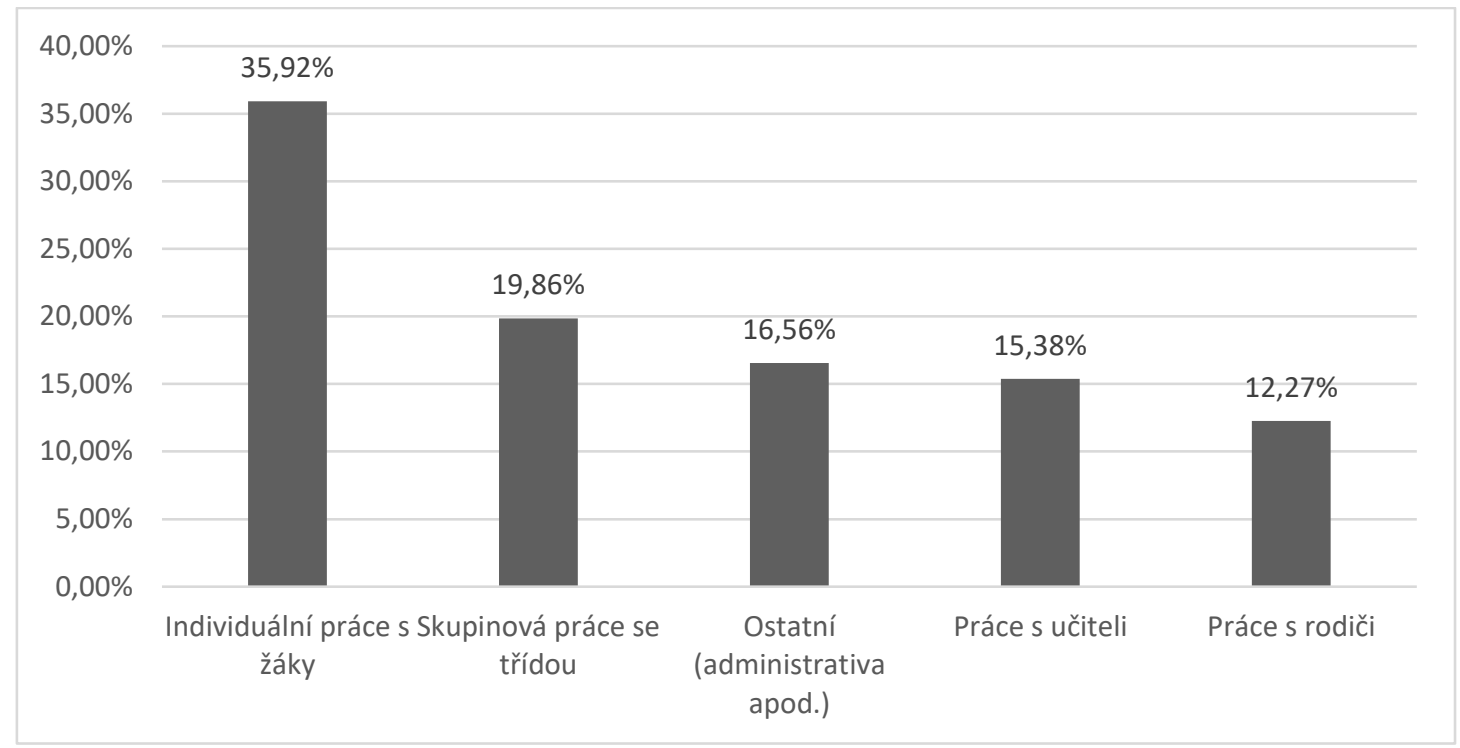

$\mathrm{Na}$ otázku, kolik vyučovacích hodin za týden odhadem školní psychologové stráví prací se tř́ídou, jsme přihlédli k nejčastěji uváděným alternativám pracovního úvazku. Tedy polovičního úvazku (průměrně 2,63 hodiny, rozmezí 0-8 hodin) a plného úvazku (průměrně 3,79 hodiny; rozmezí 0-11 hodin), jenž byly zastoupeny v 91,78 \% odpovědí.

Do tříd školní psychologové vstupují nejčastěji na žádost tř́dní učitelky 38,26 \%, pravidelně na základě vlastní iniciativy 31,51\%, nebo když má školní psycholog dojem, že by to dané třídě mohlo pomoci 20,55 \%. Oproti tomu pouze v 9,59\% na žádost vedeni školy. Výrazné rozdíly najdeme, pokud zvolíme kritérium velikosti úvazku. V př́ípadě plného úvazku školního psychologa je patrný nárůst pravidelného vstupu na základě vlastní iniciativy a zároveň pokles u odpovědi na žádost třídní učitelky.

Graf 2: Do tříd nejčastěji vstupuji

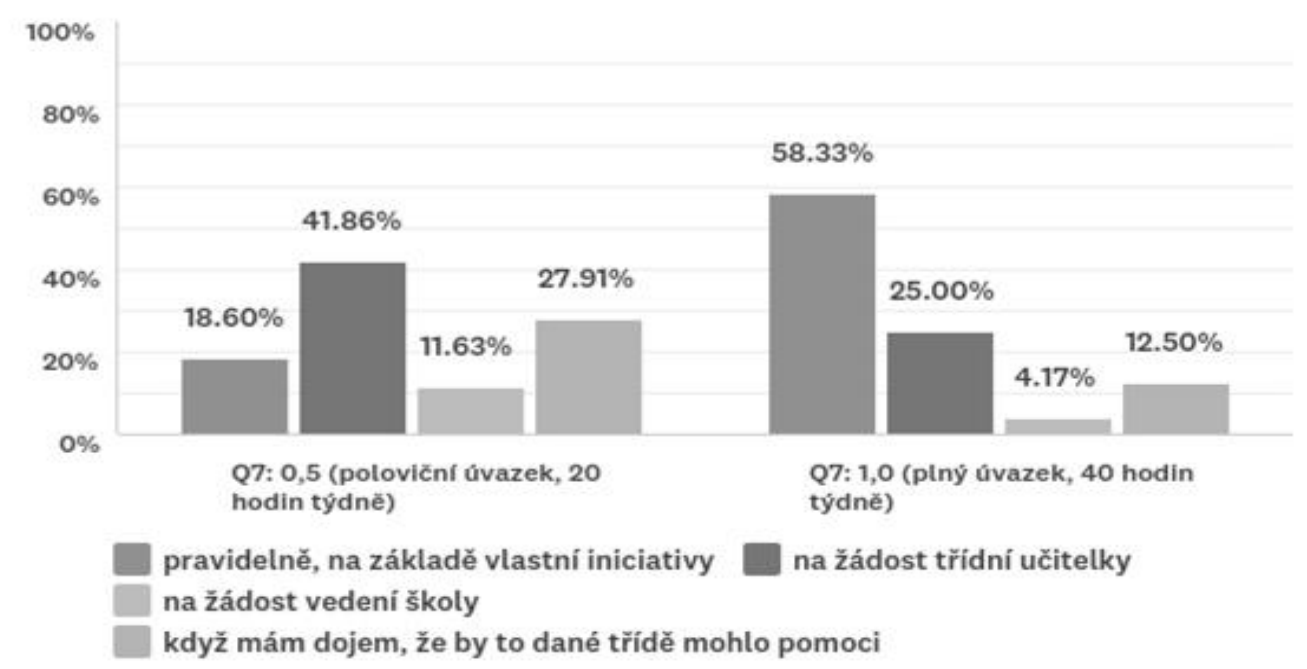




\section{Výzkumný cíl 2: Zjistit, jakým způsobem školní psychologové se třídami nejčastěji pracují}

V první části druhého výzkumného úkolu jsme se zaměřili na to, zda je při práci školního psychologa prrítomen a aktivně zapojen další odborník. Níže uvedený graf poukazuje na nejčastější prítomnost třídního učitele. V možných komentáŕích $\mathrm{k}$ této otázce se také objevoval komentář uvádějící jeho prrítomnost bez zapojení, tedy pouze v roli pozorovatele.

Graf 3: Kdo z odborníků se s vámi aktivně podílí při práci se třídou?

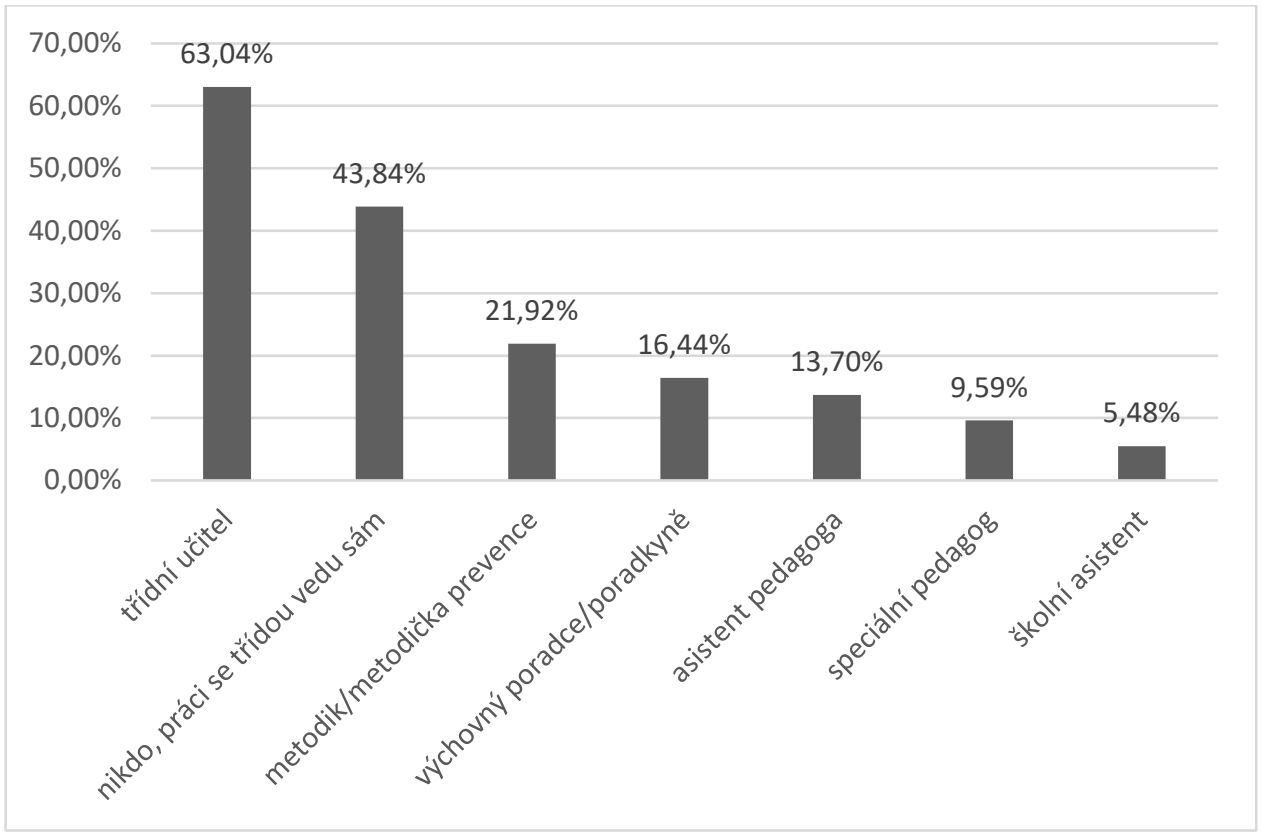

Dále měli respondenti možnost vybírat z předloženého seznamu aktivit ty, které se třídními kolektivy realizují. Tabulka 4 nabízí jejich přehled dle uváděných voleb odpovědí. Nejčastější aktivitou byla diagnostika vztahů třídního kolektivu (90,41\%), dále prožitková hodina $(82,19$ $\%$ ) a intervenční činnost s 68,49\%. Podle četnosti výskytu mezi obvyklá témata při práci se třídami patři aktuální vztahové problémy nebo role a pravidla ve třídé.

Tab. 4: Seznam aktivit, které školní psychologové se třídními kolektivy dělají

\begin{tabular}{l|l|l}
\hline \multicolumn{1}{c|}{ Aktivity } & \multicolumn{2}{c}{ Odpovědi } \\
\hline diagnostiku vztahů tř́dního kolektivu (tř́idní klima) & $90,41 \%$ & 66 \\
\hline prožitková hodina & $82,19 \%$ & 60 \\
\hline intervence & $68,49 \%$ & 50 \\
\hline dlouhodobá preventivní práce s vybranými tř́́dami & $64,38 \%$ & 47 \\
\hline adaptační kurzy (kohezivní kurzy) & $45,21 \%$ & 33 \\
\hline
\end{tabular}




\begin{tabular}{l|l|l}
\hline nácviková hodina & $36,99 \%$ & 27 \\
\hline krizová intervence & $35,62 \%$ & 26 \\
\hline třídnické hodiny & $35,62 \%$ & 26 \\
\hline jiná diagnostika třídního kolektivu & $24,66 \%$ & 18 \\
\hline Školní výlety & $23,29 \%$ & 17 \\
\hline vedení tř́dy (organizační věci, přesazení žáků) & $9,59 \%$ & 7 \\
\hline
\end{tabular}

\section{Výzkumný cíl 3: Zjistit subjektivní hodnocení vlastní kompetence školního psychologa při práci se třídou}

Těžištěm dotazníku bylo předložení 28 tvrzení v rámci 14 kategorií (např. pravidla, skupinová dynamika, viz tab. 5). Seznam tvrzení je vlastní konstrukce. Přri jeho tvorbě jsme se inspirovali metodikou zážitkové pedagogiky (Beneš a kol, 2016) a vlastní praxí.

Respondenti odpovídali na pěti bodové škále zcela souhlasím až po zcela nesouhlasím. U kategorií nervozita, hlučné děti, tvorba programu a stanovení cílů byly záměrně zvoleny i výroky s opačným hodnocením. Jednotlivá tvrzení (např. Snažím se vždy na konci hodiny ziskat od dětí informaci o tom, jak se cití nebo Všimám si, jaké postavení má žák ve třídé) byla $\mathrm{v}$ rámci dotazníku předkládána $\mathrm{v}$ náhodné rotaci, a to tím způsobem, aby po sobě nenásledovala $\mathrm{v}$ rámci zvolených kategorií. $\mathrm{V}$ tabulce níže uvádíme dosažené průměrné hodnoty pro celý soubor. Tabulka také obsahuje křížové porovnání dosažených výsledků jednotlivých tvrzení z pohledu délky praxe, výše úvazku či zda školní psychologové absolvovali další vzdělávání zaměřené na práci se třídou. Předpokládali jsme, že tyto proměnné by mohly poukázat na signifikantní rozdíly v rámci některých kategorií. Hlubší statistická analýza posouzení rozdílů průměrných hodnot však signifikantní rozdíly neprokázala.

Tab. 5: Subjektivní hodnocení vlastní kompetence při práci se trrídou

\begin{tabular}{|c|c|c|c|c|c|c|c|c|}
\hline \multirow[t]{2}{*}{ kategorie } & \multirow[t]{2}{*}{$\begin{array}{l}\text { číslo } \\
\text { položky } \\
\text { V rotaci } \\
5\end{array}$} & \multirow[t]{2}{*}{$\begin{array}{l}\text { dosažený } \\
\text { celkový } \\
\text { vážený } \\
\text { průměr }\end{array}$} & \multicolumn{2}{|c|}{$\begin{array}{l}\text { délka praxe } \\
n=73\end{array}$} & \multicolumn{2}{|c|}{$\begin{array}{l}\text { další } \\
\text { vzdělávání } \\
\text { zaměřené na } \\
\text { práci se } \\
\text { tř́ídou }\end{array}$} & \multicolumn{2}{|c|}{$\begin{array}{l}\text { výše úvazku } \\
n=67\end{array}$} \\
\hline & & & $\begin{array}{l}\text { do } 30 \\
\text { měsíců }\end{array}$ & $\begin{array}{l}\text { nad } 30 \\
\text { měsíců }\end{array}$ & ano & ne & poloviční & celý \\
\hline \multirow{2}{*}{ pravidla } & 1 & 1,93 & 2,12 & 1,83 & 1,92 & 1,94 & 2,00 & 1,88 \\
\hline & 2 & 2,16 & 2,38 & 2,04 & 2,00 & 2,34 & 2,19 & 2,04 \\
\hline
\end{tabular}

\footnotetext{
${ }^{5}$ Plné znění položek je na vyžádání u autorů výzkumu.
} 


\begin{tabular}{|c|c|c|c|c|c|c|c|c|}
\hline \multirow{2}{*}{$\begin{array}{l}\text { skupinová } \\
\text { dynamika }\end{array}$} & 3 & 1,97 & 2,08 & 1,92 & 1,93 & 2,03 & 1,91 & 1,75 \\
\hline & 4 & 1,41 & 1,46 & 1,36 & 1,37 & 1,43 & 1,47 & 1,17 \\
\hline \multirow{2}{*}{ nervozita } & 5 & $3,56^{*}$ & 3,40 & 3,72 & 3,84 & 3,26 & 3,65 & 3,58 \\
\hline & 6 & 2,68 & 2,80 & 2,62 & 2,42 & 2,97 & 2,63 & 2,58 \\
\hline \multirow{2}{*}{$\begin{array}{l}\text { role ve } \\
\text { skupině }\end{array}$} & 7 & 2,51 & 2,60 & 2,35 & 2,61 & 2,40 & 2,40 & 2,54 \\
\hline & 8 & 1,81 & 1,92 & 1,74 & 1,79 & 1,83 & 1,77 & 1,83 \\
\hline \multirow{2}{*}{ hlučné děti } & 9 & $3,53 *$ & 3,23 & 3,68 & 3,68 & 3,37 & 3,56 & 3,58 \\
\hline & 10 & 2,16 & 2,19 & 2,15 & 1,97 & 2,37 & 2,14 & 2,04 \\
\hline \multirow{2}{*}{$\begin{array}{c}\text { neaktivní } \\
\text { děti }\end{array}$} & 11 & 2,12 & 2,34 & 2,00 & 1,87 & 2,40 & 2,19 & 1,92 \\
\hline & 12 & 2,32 & 2,38 & 2,28 & 2,13 & 2,51 & 2,37 & 2,17 \\
\hline \multirow{2}{*}{$\begin{array}{c}\text { tvorba } \\
\text { programu }\end{array}$} & 13 & $3,53 *$ & 3,27 & 3,68 & 3,76 & 3,29 & 3,53 & 3,63 \\
\hline & 14 & 2,12 & 2,23 & 2,06 & 1,95 & 2,31 & 2,09 & 2,08 \\
\hline \multirow{2}{*}{$\begin{array}{l}\text { programové } \\
\text { prostředky }\end{array}$} & 15 & 2,03 & 2,15 & 1,96 & 1,87 & 2,2 & 2,07 & 1,79 \\
\hline & 16 & 2,05 & 2,31 & 1,91 & 1,92 & 2,2 & 2,12 & 1,84 \\
\hline \multirow{2}{*}{$\begin{array}{l}\text { zjišs'ování } \\
\text { nálady před }\end{array}$} & 17 & 2,32 & 2,65 & 2,13 & 2,26 & 2,37 & 2,33 & 2,29 \\
\hline & 18 & 1,86 & 1,96 & 1,81 & 1,95 & 1,77 & 1,84 & 1,96 \\
\hline \multirow{2}{*}{$\begin{array}{l}\text { zjišt’ování } \\
\text { nálady po }\end{array}$} & 19 & 1,93 & 2,19 & 1,78 & 1,97 & 1,89 & 1,95 & 1,88 \\
\hline & 20 & 2,11 & 2,23 & 2,04 & 2,08 & 2,1 & 2,05 & 2,13 \\
\hline \multirow{2}{*}{ reflexe } & 21 & 1,79 & 1,73 & 1,83 & 1,71 & 1,89 & 1,91 & 1,67 \\
\hline & 22 & 1,63 & 1,65 & 1,62 & 1,55 & 1,71 & 1,72 & 1,50 \\
\hline \multirow{2}{*}{$\begin{array}{c}\text { stanovení } \\
\text { cílů }\end{array}$} & 23 & 2,07 & 2,15 & 2,02 & 2,08 & 2,06 & 2,02 & 2,21 \\
\hline & 24 & 3.86* & 3,77 & 3,91 & 4,00 & 3,71 & 3,81 & 3,88 \\
\hline \multirow{2}{*}{$\begin{array}{l}\text { hodnocení } \\
\text { kompetencí }\end{array}$} & 25 & 2,12 & 2,01 & 2,20 & 1,82 & 2,46 & 2,21 & 1,88 \\
\hline & 26 & 2,45 & 2,54 & 2,40 & 2,26 & 2,66 & 2.42 & 2,38 \\
\hline \multirow{2}{*}{ intervence } & 27 & 2,48 & 2,78 & 2,32 & 2,21 & 2,77 & 2,37 & 2,50 \\
\hline & 28 & 1,86 & 2,80 & 1,44 & 1,71 & 2,03 & 1,91 & 1,75 \\
\hline
\end{tabular}

Pro doplnění uvádíme v tabulce níže subjektivní vnímání limitů při práci s třídními kolektivy. Využili jsme dvou kategorií, kdy na jedné straně uvádí školní psychologové své vlastní limity a na straně druhé limity ze strany školy či dalších zainteresovaných účastníků. 
Tab. 6: Jaké limity při práci se tř́́dou vnímáte? $(n=73)$

\begin{tabular}{|c|c|}
\hline limity na straně školního psychologa & $\begin{array}{l}\text { limity na straně školy či dalších zainteresovaných } \\
\text { stran }\end{array}$ \\
\hline $\begin{array}{l}\text { špatné plánování času, nedostatečný časový prostor } \\
\text { z důvodu jiné práce }\end{array}$ & $\begin{array}{l}\text { malá spolupráce ze strany pedagogů, ne úplně } \\
\text { pozitivní nastavení učitelů }\end{array}$ \\
\hline $\begin{array}{l}\text { doposud nedostatečný repertoár osvědčených metod, } \\
\text { nedostatečná znalost technik a aktivit }\end{array}$ & $\begin{array}{l}\text { chybějící proškolení v odborné pedagogické práci se } \\
\text { třídou nebo vedením třídnických hodin }\end{array}$ \\
\hline $\begin{array}{l}\text { minimální zkušenosti práce se třídou, krátké } \\
\text { působení na škole, nedostatečná praxe }\end{array}$ & $\begin{array}{l}\text { nutnost až „,prošení“ pedagogů, kteří tím o svou } \\
\text { hodinu ,přijdou“, nedostatečný časový prostor }\end{array}$ \\
\hline $\begin{array}{l}\text { problém s hlučností třídy i přes nastavená } \\
\text { komunikační pravidla }\end{array}$ & nedostatečné informace o třídě nebo nejasná zakázka \\
\hline nejsem dostatečně autoritativní člověk & velký počet žáků ve třídě \\
\hline $\begin{array}{l}\text { malý zájem o práci s třídním kolektivem, důraz na } \\
\text { individuální práci }\end{array}$ & rodiče si někdy stěžují, že se zanedbává výuka \\
\hline $\begin{array}{l}\text { vnitřní nejistota při práci se třídou, nedostatek } \\
\text { kompetencí k řešení vážnějších témat }\end{array}$ & $\begin{array}{l}\text { málo zakázek ze strany školy, malá podpora ze strany } \\
\text { vedení }\end{array}$ \\
\hline otázka motivace žáků & různé představy o výsledku i procesu \\
\hline $\begin{array}{l}\text { stanovení si nereálných cílů, lépe pracovat s pravidly, } \\
\text { vysoká očekávání }\end{array}$ & nevhodné prostory, výše úvazku \\
\hline \multirow[t]{2}{*}{ potřeba dalšího vzdělávání a hledání financování } & $\begin{array}{l}\text { situace, kdy pedagog neumí z prožitkových hodin } \\
\text { vytěžit přesah do praxe }\end{array}$ \\
\hline & $\begin{array}{l}\text { chybějící návaznost na moji práci, legislativní } \\
\text { překážky v rámci (ne)souhlasu rodičů }\end{array}$ \\
\hline
\end{tabular}

\section{Diskuse}

Podle Štecha a Zapletalové (2011) patří k rozhodujícím faktorům efektivity činnosti školního psychologa ve škole vztahy s vedením školy, zejména pak začlenění do systému školy a vyjasnění představ o fungování školního psychologa. Za významný zátěžový moment byl považován vztah s učiteli. Z tohoto důvodu bylo pro nás důležité zjištovat, jak tyto aspekty své práce vnímají respondenti zapojení do našeho výzkumu. Na otázku, jak se školní psychologové cítí přijímáni, jsme na škále 1-5, kdy 1 znamená nejlépe, zjistili průměrné hodnoty na úrovni vedení školy $(1,58)$, žáků $(1,56)$, metodiků prevence $(1,63)$ a výchovných poradců $(1,53)$. V kategorii spíše přijímán byly nejvíce zastoupeny odpovědi ze strany pedagogů $(1,92)$, či rodičů $(1,85)$. Z praxe a supervizních rozhovorů, často vyplývá obtížnost adaptace školního 
psychologa na konkrétní škole, která zahrnuje s vztah s vedením školy a pedagogy. Existují evidence o př́padech, kdy školní psycholog není na škole vítán/přijímán či dokonce nemá podporu ze strany vedení školy apod. Výše uvedené výsledky však hovoří jinak. Domníváme se, že zde hraje roli zapojení těch školních psychologů, kteří bud' již mají adaptační proces úspěšně za sebou a podařilo se jim vybudovat patřičnou pozici na konkrétní škole, nebo těch, kteří jsou na škole opravdu žádáni a vítáni.

V rámci prvního výzkumného cíle jsme zjišstovali zastoupení práce se třídou v celkové činnosti školního psychologa. Jednalo se o třetí nejčastěji uváděnou činnost pracovní náplně. Obdobné výsledky uvádí studie Lazarové a Ondruše (2000), podle nichž školní psychologové vykonávají především poradenství pro děti, práci s rodiči a v menší míře skupinovou práci s dětmi. Pokud se na vybrané pracovní činnosti podíváme z pohledu distribuce času, zaujímá skupinová práce se třídou druhé místo $(19,86$ \%) za individuální prací s žáky. Srovnatelná zjištění přináší i studie Štecha a Zapletalové (2001), kdy nejvíce času věnuje školní psycholog práci s jednotlivými žáky. Komplikaci pak pro školní psychology představuje zejména nedostatek času pro práci $\mathrm{s}$ tř́ídami a finanční prostředky pro další vzdělávání v této oblasti. Zdá se, že důležitou proměnnou je úvazek a působení školního psychologa na konkrétní škole.

V prř́padě plného úvazku je v našem př́spěvku patrný nárůst pravidelného vstupu ,na základě vlastní iniciativy“ - viz graf 2. (tedy zná více trrídní kolektivy; lépe odhadne, kdy je do tříd potřeba vstupovat; realizuje depistážní šetření a prevenci) a zároveň pokles u možnosti „na žádost tř́íní učitelky“.

Druhým cílem bylo zjistit, jaké formy práce se třídou školní psychologové realizují. Nejčastěji to je diagnostika vztahů třídního kolektivu, prožitková hodina, intervence, dlouhodobá preventivní práce s vybranými třídami, adaptační kurzy, nácvikové hodiny a krizové intervence. Naše výsledky naznačují, že školní psychologové pracují se třídními kolektivy především v situacích vyšší náročnosti metodických postupů a př́ípravy. Naše výsledky částečně odpovídají úrovním preventivních vstupů do třídy dle autorů Brauna, Markové a Nováčkové (2014), přičemž uváděný seznam nemá vylučovací charakter. To znamená, že se jednotlivé úrovně se mohou překrývat či doplňovat.

Třetím výzkumným cílem bylo zjistit subjektivní hodnocení vlastní kompetence školního psychologa při práci se trrídou. Na výsledky bylo nahlíženo z celkového pohledu všech respondentů a následně z pohledu stanovených kritérií, tedy délky praxe, dalšího vzdělávání zaměřeného na práci se tř́idou a výše úvazku. Naměřené průměrné hodnoty na pěti bodové škále u jednotlivých tvrzení se pohybují od 1,41 až po 2,68. Z obecného hlediska hodnotí sami školní psychologové vlastní kompetence za dobře zvládnuté v kategoriích reflexe a skupinová dynamika, méně si věří v kategorii nervozita, neaktivní děti a hodnocení kompetencí.

Velkým úskalím práce školního psychologa se tř́dami je to, že v české odborné literatuře toto téma zatím nebylo př́liš zpracováno. Představovanou studii tedy vnímáme jako první mapující výzkum na toto téma, z čehož plynou mnohé otazníky a limity. Prvním z nich je sběr dat prostřednictvím internetu, který je stále poměrně diskutabilním způsobem získávání výzkumných dat. Stejně tak jako i jiné způsoby, tak i elektronické dotazování v sobě zahrnuje 
výhody a nevýhody. Nejednalo se o náhodný výběr, nýbrž svým charakterem odpovídal spíše technice sněhové koule. Domníváme se, že tento způsob sběru dat mohl ovlivnit některé výsledky. Druhá oblast limitů zahrnuje malý rozsah výzkumného vzorku a z hlediska pohlaví nerovnoměrné zastoupení. Ženy představují $92 \%$ respondenti̊, což nemusí reflektovat složení školních psychologů. Třetí omezení souvisí s metodami získávání dat. Pracovali jsme se sebeposuzovacím nástrojem vlastní konstrukce. I v tomto př́ípadě se domníváme, že existuje možnost zkreslení výpovědí respondentů. Posledním omezením sami autoři vnímají nejasně zakotvenou terminologii a definice jednotlivých činností, jenž jsou na pomezí pedagogiky a psychologie. Příkladem může být vedení třídy, kdy je myšleno spíše třídnické vedení ze strany pedagoga, oproti psychologickému vnímání práce se skupinovou dynamikou. Z výše uvedených důvodu je nutné $\mathrm{k}$ interpretaci výsledků přistupovat $\mathrm{s}$ jistou obezřetností.

Budoucí výzkum by mohl směřovat $\mathrm{k}$ minimalizaci výše uvedených nedostatků. Především by byl vhodné lépe definičně ošetřit vymezení jednotlivých pracovních činností např́iklad uvedením vysvětlení či př́ikladu co konkrétní kategorie zahrnuje. Nabízí se tak předpoklad realizovat smíšený design výzkumu a ověřit zjištěné vztahy na větším výzkumném souboru, stejně tak i s využitím hloubkových rozhovorů či focusových skupin. Vzhledem ke skutečnosti, že v naší práci respondenti poukazují na chybějící metodickou podporu a vedení, domníváme se, že jedna z cest by mohla vést $\mathrm{k}$ hlubšímu objasnění specifických zakázek při práci s trrídními kolektivy a jak se s nimi školní psychologové vyrovnávají.

\section{Závěr}

Zakázka pro práci školního psychologa s třídním kolektivem bývá často specifická, a právě i z tohoto důvodu není jednoduché najít potřebnou metodickou podporu. Školní psychologové se s touto situací vyrovnávají především svým aktivním př́istupem a kreativitou. Rádi bychom náš př́ispěvek zakončili vzkazy kolegům od školních psychologů, které jsme nazvali Poselství pro: Určitě se všechno nepodaři podle našich představ, ale je důležité tu být pro ty, kteři to potřebují. Systematická práce s tř́dním kolektivem je základem prevence. Někdy je to náročné, ale obvykle je to radost a někdy i euforie. Žáci si chtěji hrát a povidat si. Pomáhejte učitelům, dělat ji efektivně. Nebojte se vstupovat do konfliktů mezi jednotlivci v různých sociálních skupinách, nebojte se pracovat se tř́dou jako celkem jakoukoliv formou (při vyučování, při sportovni hře, při volnočasové aktivitě). Nenechejte se zaměstnat jako ŠP ve škole, kde tuto činnost podceñuje ředitel/ka. Nepracujte jako ŠP ve škole, kde nemáte vlastni pracovnu a musite se přizpo̊sobovat "spolubydlicim". Spolupracujte, pozorujte a držet se zakázky. Nebud'te v tom sami a bud'te kreativní.

Dedikace k projektu:

Příspěvek vznikl za podpory MŠMT, grant IGA_FF_2018_019 (Psychologický výzkum ve vybraných oblastech pedagogické a klinické psychologie III) a IGA_FF_2019_016 (Psychologický výzkum ve vybraných oblastech pedagogické a klinické psychologie IV). 


\section{Literatura}

Allen, M., Jerome, A., White, A., Marston, S., Lamb, S., Pope, D., \& Rawlins, C. (2002). The preparation of school psychologists for crisis intervention. Psychology in the Schools, 39(4), 427-439.

Artamonova, E. G., Efimova, O. I., \& Khydyrova, A. V. (2016). Psychologist in the Educational System: His Role in the Prevention of Addiction and Deviance. International Journal of Environmental and Science Education, 11(17), 9891-9901.

Bartoňová, M., Pipeková, J., Viktorin, J., Vítková, M. (2019). Rozšíření školního poradenského pracoviště o pozici školního speciálního pedagoga a školního psychologa. Online Journal of Primary and Preschool Education, 3 (1). https://doi.org/10.21062/ujep/326.2019/a/2533-7106/ojppe/2019/3/1

Beneš, Z. a kol. (2016). Instruktorský slabikářr: metodická přiručka pro všechny, kdo organizuji kurzy zážitkové pedagogiky. Praha: Nadační fond Gymnasion.

Branden-Muller, L. R., \& Elias, M. J. (1991). Catalyzing the Primary Prevention Revolution in the Schools: The Role of School Psychologists. Journal of Educational \& Psychological Consultation, 2(1), 73.

Braun, R., Marková, D., \& Nováčková, J. (2014). Praktikum školní psychologie. Praha: Portál.

Braun, R., Marková, D., Nováčková, J. (2014). Praktikum školní psychologie. Praha: Portál. Čapek, R. (2010). Tř́dní klima a školni klima. Praha: Grada.

Fenning, P., Diaz, Y., Valley-Gray, S., Cash, R. G., Spearman, C., Hazel, C. E., ... \& Harris, A. (2015). Perceptions of competencies among school psychology trainers and practitioners: What matters? Psychology in the Schools, 52(10), 1032-1041. https://doi.org/10.1002/pits.21877

Gajdošová, E. (2017). Nové výzvy a nové úlohy školských psychológov v kontexte európskej a slovenskej politiky zdravia. Školský psychológ / Školní psycholog, 18(1), 8-13 .

Gajdošová, E., Herényiová, G., \& Valihorová, M. (2010). Školská psychológia. Bratislava: Stimul.

Gillernová, I., Krejčová, L. et al. (2012). Sociální dovednosti ve škole. Praha: Grada.

Hermochová, S. (2005). Skupinová dynamika ve školní třídè. Kladno: Aisis.

Hertz-Lazarowitz, R., \& Od-Cohen, M. (1992). The school psychologist as a facilitator of a community-wide project to enhance positive learning climate in elementary schools. Psychology in the Schools, 29(4), 348-358. https://doi.org/10.1002/15206807(199210)29:4<348::aid-pits2310290408>3.0.co;2-d

Hvozdík, J. (1986). Základy školskej psychológie. Bratislava: Slovenské pedagogické nakladatel'stvo.

Janošová, P., Kollerová, L., Zábrodská, K., Kressa, J., Dědová, M. (2016). Psychologie školní šikany. Praha: Grada.

Ježek, S. (2006). Možnosti diagnostiky psychosociálního klimatu školy. (Nepublikovaná disertační práce). Brno: Masarykova univerzita.

Kavenská, V., Smékalová, E., \& Šmahaj, J. (2011). Výzkum v oblasti školní psychologie v České republice. E-psychologie, 5(4), 55-67. https://e-psycholog.eu/clanek/133

Keřt, R. (2014). Kritická mista profese školních psychologů. (Nepublikovaná diplomová práce). Univerzita Palackého v Olomouci.

Kozel, M. (2010). Skupinová dynamika školních tříd. (Nepublikovaná diplomová práce). Praha: Univerzita Karlova.

Lašek, J. (2007). Sociálně psychologické klima školnich tř́d a školy. Hradec Králové: Gaudeamus. 
Lazarová, B. (2008). Školní psychologie v České republice po roce 1989. Československá psychologie, 52(5), 480-492.

Lazarová, B., \& Ondruš, D. (2000). Dva pohledy na náplň práce školního psychologa. Školský psychológ, 10, 2-10.

Lazarová, B., Hloušková, L., Pol, M., \& Trnková, K. (2017). Proměny práce školních psychologů v proinkluzivně naladěných školách. Pedagogická orientace, 27(2), 287-307. https://doi.org/10.5817/pedor2017-2-287

Mareš, J. (2016). Školní psycholog jako výzkumník: zamyšlení nad možnostmi. Pedagogická orientace, 26(1), 5-23. https://doi.org/10.5817/pedor2016-1-5

Mareš, J. (2017). Morální distres školních psychologů. Pedagogická orientace, 27(2), 308343. https://doi.org/10.5817/pedor2017-2-308

Mareš, J., Ježek, S. (2012). Klima školní třídy. Dotazník pro žáky. Praha: Národní ústav pro vzdělávání.

Matasová, L. (2012). Krizová intervence ve škole. (Nepublikovaná diplomová práce). Praha: Univerzita Karlova.

Melovská, M. (2009). Psychosociální klima školních tříd na základní škole s působením školního psychologa. (Nepublikovaná bakalářská práce). Olomouc: Univerzita Palackého.

Merrell, K. V., Ervin, R. A., \& Peacock, G. G. (2011). School psychology for the 21st century: Foundations and practices. New York: Guilford Press.

Nickerson. A. B., Zhe, Elizabeth J. (2004). Crisis prevention and intervention: a survey of school psychologists. Psychology in the Schools, 41(7), 777-788. https://doi.org/10.1037/e345062004-001

Palová, K., Smékalová, E. (2019). Program Druhý krok: Dosavadní výsledky ověřování efektivity v České republice. In Maierová, E., Viktorová, L., Dolejš, M., Dominik, T. (Eds.), PhD Existence 2019: Tělo a mysl. Sborník odborných přispěvků (217224).Olomouc: Univerzita Palackého

Paulová, J. (2017). Preventivní program ve středisku výchovné péče jako forma intervence pro tř́dy s narušeným klimatem. (Nepublikovaná diplomová práce). Brno: Masarykova univerzita.

Pilková, J. (2017). Participácia školského psychológa na podpore duševného zdravia žiakov. Školský psychológ / Školní psycholog, 18(1), 50-54.

Plachá, V. (2017). Proces truchlení v prostředí ZŠ. Školský psychológ / Školní psycholog, 18 (1).

Seligman, M. E., Ernst, R. M., Gillham, J., Reivich, K., \& Linkins, M. (2009). Positive education: Positive psychology and classroom interventions. Oxford review of education, 35(3), 293-311. https://doi.org/10.1080/03054980902934563

Sherer, Y. C., \& Nickerson, A. B. (2010). Anti-bullying practices in American schools: Perspectives of school psychologists. Psychology in the Schools, 47(3), 217-229. https://doi.org/10.1002/pits.20466

Slejšková, L. (Ed.). (2011). Škola zážitkem. Praha: Prázdninová škola Lipnice.

Smékalová, E., \& Kolařík, M. (2011). Typy třídních kolektivů a způsoby práce s nimi aneb mocenský, nebo demokratický přístup? Prevence, 7(9), 10-12.

Štech, S. (2001). Sonda do profese školního psychologa v ČR. Pedagogika, 51, 47-55.

Štech, S., \& Zapletalová, J. (2013). Úvod do školní psychologie. Praha: Portál.

TIBCO Software Inc. (2017). Statistica (data analysis software system), version 13. http://statistica.io.

Titmanová, M. (2019). Klima ve školní třídě aneb šikana v praxi. Školský psychológ / Školní psycholog, 20(1). 
Váchová, E. (2016). Metody intervence vedoucí k začlenění dítěte v riziku poruch chování a s poruchami chování do kolektivu. (Nepublikovaná diplomová práce). Brno: Masarykova univerzita.

Valenta, J. (2013). Didaktika osobnostní a sociální výchovy. Praha: Grada.

Waters, L. (2011). A review of school-based positive psychology interventions. The Educational and Developmental Psychologist, 28(2), 75-90. https://doi.org/10.1375/aedp.28.2.75

\section{O autorech}

Mgr. Kateřina Palová působí na Katedře psychologie FF UP jako asistentka v oblasti pedagogické psychologie, v témže oboru dokončuje doktorské studium. Dlouhodobě se věnuje volnočasové práci s dětmi a mládeží, aktivně spolupracuje s NPI ČR. Má pracovní zkušenosti jako školní psycholog, krizový intervent či lektor kurzů určených pro učitele. V rámci své odborné profilace se zaměřuje na problematiku sociálně-emocionálního učení, školní psychologii, zážitkovou a volnočasovou pedagogiku.

Kontaktní údaje:

Adresa: Katedra psychologie FF UP, Vodární 6, 77180 Olomouc

E-mail: katerina.palova@upol.cz

PhDr. Jan Šmahaj Ph.D. působí jako odborný asistent na Katedře psychologie UP v Olomouci. Dlouhodobě se teoreticky a výzkumně zabývá problematikou kyberšikany a virtuálního prostředí, mezilidskou komunikací a kyberpsychologií. Mezi jeho další zájmy patří pedagogická/školní psychologie, sociální psychologie a oblast výzkumu prostřednictvím moderních komunikačních prostředků. Aktuálně se s kolegy věnuje výzkumu v oblasti využití virtuální reality.

Kontaktní údaje:

Adresa: Katedra psychologie FF UP, Vodární 6, 77180 Olomouc

E-mail: jan.smahaj@upol.cz

Palová, K, \& Šmahaj, J. (2020). Práce školního psychologa se tř́idou na základních školách. E-psychologie, 14(1), 1-18. https://doi.org./10.29364/epsy.363 